\title{
CORRECTION
}

\section{Correction to: Electric hybridization kit for modification of a manual transmission motorcycle}

\author{
Published online: 20 February 2020 \\ (c) Springer-Verlag France SAS, part of Springer Nature 2020

\section{Correction to:} \\ International Journal on Interactive Design \\ and Manufacturing (IJIDeM) \\ https://doi.org/10.1007/s12008-020-00649-w
}

Simón Polanía-Restrepo ${ }^{1}\left[\right.$ [ $\cdot$ Santiago Jaramillo-González ${ }^{1} \cdot$ Gilberto Osorio-Gómez $^{1}$

Unfortunately, the corresponding author name was incorrectly spelled as "Simán Polanía-Restrepo" instead of 'Simón Polania-Restrepo" in the original publication. The correct version of author name is updated here.

The original article has been corrected.

Publisher's Note Springer Nature remains neutral with regard to jurisdictional claims in published maps and institutional affiliations.

The original article can be found online at https://doi.org/10.1007/ s12008-020-00649-w.

Simón Polanía-Restrepo

spolani1@eafit.edu.co

Santiago Jaramillo-González

sjaram25@eafit.edu.co

Gilberto Osorio-Gómez

gosoriog@eafit.edu.co

1 Design Engineering Research Group (GRID), Universidad EAFIT, Carrera 49, \# 7 sur 50, PO Box 050022, Medellín, Antioquia, Colombia 